\title{
Assessment of fish species richness and physicochemical parameters of Mt. Hamiguitan Range Wildlife Sanctuary river systems in Mindanao, Philippines
}

\author{
MARK LLOYD G. DAPAR ${ }^{1,2,3, \boldsymbol{v}}$, APRIL JOIE D. LAGUMBAY ${ }^{1,3}$, JULIUS PARCON $^{4}$, \\ ROMEO M. TUBONGBANUA JR. ${ }^{1}$, VICTOR B. AMOROSO ${ }^{1,3}$ \\ ${ }^{1}$ Center for Biodiversity Research and Extension in Mindanao (CEBREM), Central Mindanao University, University Town, Musuan, Bukidnon 8714, \\ Philippines, `email: f.marklloyd.dapar.gs@ @ cmu.edu.ph \\ ${ }^{2}$ Microtechnique and Systematics Laboratory, Natural Science Research Center, Central Mindanao University, University Town, Musuan, Bukidnon \\ 8714, Philippines \\ ${ }^{3}$ Department of Biology, College of Arts and Sciences, Central Mindanao University, University Town, Musuan, Bukidnon 8714, Philippines \\ ${ }^{4}$ Museum of Natural History, University of the Philippines Los Baños, Laguna 4031, Philippines
}

Manuscript received: 2 October 2021. Revision accepted: 21 November 2021.

\begin{abstract}
Dapar MLG, Lagumbay AJD, Parcon J, Tubongbanua Jr. RM, Amoroso VB. 2021. Assessment of fish species richness and physicochemical parameters of Mt. Hamiguitan Range Wildlife Sanctuary river systems in Mindanao, Philippines. Intl J Bonorowo Wetlands 11: 58-68. Being a UNESCO World Heritage Site, Mt. Hamiguitan Range Wildlife Sanctuary (MHRWS) is an exceptional area of diverse flora and fauna with conservation concerns. MHRWS river systems provide significant spawning and nursery grounds for freshwater fishes. However, anthropogenic activities may result in the degradation of fish habitats which calls for conservation. This study provides an updated assessment of the fish diversity of selected MHRWS river systems and recommends policies for the proper management of the rivers and riparian ecosystems. An inventory of fish species and an assessment of the physicochemical parameters were conducted in the three river systems of Mt. Hamiguitan Range Wildlife Sanctuary. A series of line transect of $100 \mathrm{~m}$ were established along the banks of the three rivers in three sampling stations (upstream, midstream, and downstream). Results showed that the Dumagooc River has the highest fish species than Maug and Banahaw River. Generally, the species richness increased from upstream to downstream. The high species richness observed upstream, and midstream is due to the presence of an intact forest with areas far from human disturbances. A total of 31 species in 11 families comprising 121 individuals were collected and identified. Of these, one endemic species, 29 native species, and two introduced species were identified, representing $4.16 \%$ of 48 species recorded in the country. As to the physicochemical characteristics of the three river systems, the results showed that the temperature, $\mathrm{pH}, \mathrm{NTU}$, and DO values of the sampling sites are within the minimum acceptable limit to be considered as within the standards for class AA, A, and B rivers.
\end{abstract}

Keywords: Endemic, introduced, inventory, native, policies, water quality

\section{INTRODUCTION}

The Philippines is one of the mega-diverse countries recognized by the United Nations Environment Programme (UNEP) World Conservation Monitoring Centre and, at the same time, a biodiversity hotspot (Heaney et al. 2004; Mallari et al. 2001). The Philippines hosts about 3,010 fish species with only $343(10 \%)$ species occurring in freshwater, of which 83 species are endemic, 206 species are native, 44 species are introduced, and 42 species are of uncertain status (Froese and Pauly 2011). However, most fish studies conducted in the country were devoted to marine ecosystems, and little is known about the freshwater diversity (Ong et al., 2002). Marine and freshwater fishes are equally valuable as bioindicators of ecosystem health and an integral part of our country's natural heritage ( $\mathrm{Ng}$ et al. 1998; Vallejo 1986). Many unique freshwater fishes, particularly gobies, pipefish, and halfbeaks, are restricted only to isolated lakes and rivers in major islands in the Philippines, but their current status in the surrounding freshwater habitats is unknown (Butler 2006; Herre 1953; Paller et al. 2011).
Rivers in the Philippines, as in other countries, support a rich but barely known biota (Allen 1991). However, most of these rivers have remained poorly understood and less studied despite their significant functions in human populations (Kottelat and Whitten 1993). Freshwater fishes are among the most endangered groups because of their high vulnerability to aquatic habitat modification (Kang et al., 2009; Laffaille et al., 2005; Sarkar et al., 2008). Among known hazards affecting rivers are habitat degradation, conversion to private use, impacts of climate change and pollution, overexploitation, and introduction of invasive species (Bagarinao 2001; Cagauan 2007).

Several studies on freshwater fish were conducted in the rivers and lakes of Mindanao. Manacop (1953) studied the life history and habits of gobies in the Cagayan River, while Myers (1960) examined the endemic fish fauna of Lake Lanao. Recent studies were conducted by Vedra et al. (2013) on the goby population in Mandulog River at Iligan City and its potential in the fishery resources (Vedra and Ocampo 2014). Uy et al. (2015) studied the productivity and biodiversity of Lake Mainit, including the fish inventory in the lake and its outlet. The most recent study 
on freshwater fish was conducted by Quimpang et al. (2015) in the five long-term ecological research (LTER) sites in Mindanao, including selected rivers of Mt. Hamiguitan Range Wildlife Sanctuary (MHRWS).

Mt. Hamiguitan Range Wildlife Sanctuary, located in Davao Oriental Province, Mindanao, is a protected area covering 6,834 ha between $6^{\circ} 40 ' \mathrm{~N}$ to $6^{\circ} 47 \mathrm{~N}$ and 126 ${ }^{\circ} 09$ ' $\mathrm{E}$ to $126^{\circ} 13$ ' $\mathrm{E}$ with the highest elevation of 1,637 masl. (Karger et al., 2012). It was designated as a UNESCO World Heritage Site in June of 2014 and is known as the Mindanao Long Term Ecological Research Site (Amoroso and Aspiras 2011). Mt. Hamiguitan serves as headwater of several major rivers such as Bitaogan River, Tibanban, Maua River, Dumagooc, and numerous creeks with discharge points to the Davao Gulf on the river West and the Philippine Sea on the East. The three major rivers are the water source to irrigate the lowlands of the municipality of Governor Generoso. The river systems emanate from usually forested hinterlands and receive organic materials to be recycled, contribute to the river's energy, support its high biodiversity and productivity (Giller and Malmqvist 1998), and serve as food sources, primarily for fishes (Vannote et al. 1980). Thus, the freshwater fish assessment provides information about their community, structure, and composition. It will also update the new list of freshwater fish found in the area.

This study, therefore, aims to assess the species richness of the fish about physicochemical characteristics of the river systems and recommend policies for the conservation and proper management strategies.

\section{MATERIALS AND METHODS}

\section{Study area}

Freshwater fishes were inventoried in the three river systems of Mt. Hamiguitan Range Wildlife Sanctuary, as described in Table 1.

Maug River is a $10 \mathrm{~km}$ river located in Sitio Tumaliti (06⒍776’N, $\left.126^{\circ} 05.517^{\prime} \mathrm{E}\right)$, San Isidro, Davao Oriental, Philippines. It has a primary and secondary forest upstream (Puting Bato), a secondary forest with an agroecosystem in the midstream. Small scale quarry, residential area, and high valued crops are present downstream (Table 1). Dumagooc river is in Barangay Osmena (06 $\left.41.903^{\prime} \mathrm{N}, 126^{\circ} 06.596^{\prime} \mathrm{E}\right)$, Governor Generoso, Davao Oriental. It has a thick primary forest upstream. Homes such as residential areas, schools, and bridges are observed near the midstream area with few trees such as fig trees (Ficus spp.), kalingag (Cinnamomum sp.), and coconuts. Some of the residents do their laundry in the river. The barangay center is located near the downstream area, where there are many houses, schools, and bridges. Banahaw river is in Barangay Surop, Governor Generoso, Davao Oriental. This location is an agroecosystem forest with a vast plantation of coconut. The downstream is also located at the center of the barangay, where some of the residents do their laundry.

The study was conducted from August 2019 to January 2021 at the Dumagooc river of Brgy. Osmeña, Governor Generoso, Maug of Sitio Tumaliti, San Isidro, Davao Oriental, and Banahaw River, Barangay Surop, Governor Generoso, Davao Oriental, Philippines (Figure 1). Three stations were assigned to collect fish and water quality parameters (Upstream, Midstream, and Downstream). Each station was sampled equally during the year's dry season to avoid possible floods and landslides in the area.

\section{Entry protocol}

Gratuitous Permit (GP) was obtained from the Department of Environment and Natural ResourcesProtected Areas Management Board (DENR-PAMB). The study was accompanied by representatives from the DENR-PAMB and the Provincial Environment and Natural Resources (PENRO) of DENR XI.

\section{Sampling design}

Three stations were selected for each of the three sites (Figure 1). A 100-meter stream reach was chosen at each station (upstream, midstream, and downstream) using a measuring tape. Before fish collection, parameters like water temperature, $\mathrm{pH}$, electrical conductivity (EC), turbidity, dissolved oxygen (DO), and total dissolved solids (TDS) were measured in situ using a Pro DSS multi-parameter probe. Nine sampling points were randomly selected in every river sampling station close to the right and left riverbanks and in the middle of the river with triplicates.

Table 1. Elevation, location, and land use of selected study sites

\begin{tabular}{|c|c|c|c|c|}
\hline \multirow{2}{*}{ Site } & \multirow{2}{*}{$\begin{array}{c}\text { Elevation } \\
\text { (m. asl.) }\end{array}$} & \multicolumn{2}{|c|}{ Location } & \multirow{2}{*}{-Surrounding land uses } \\
\hline & & $\mathbf{N}$ & $\mathbf{E}$ & \\
\hline \multicolumn{5}{|c|}{ Maug River } \\
\hline MUS & 240 & $06^{\circ} 69.776^{\prime}$ & $126^{\circ} 15.020^{\prime}$ & Primary forest (Puting Bato) \\
\hline MMS & 131 & $06^{\circ} 43.735^{\prime}$ & $126^{\circ} 07.786^{\prime}$ & Secondary forest \\
\hline MDS & 44 & $06^{\circ} 41.968^{\prime}$ & $126^{\circ} 05.517^{\prime}$ & Small scale quarry, residential area, and high valued crops \\
\hline \multicolumn{5}{|c|}{ Dumagooc River } \\
\hline DUS & 209 & $06^{\circ} 41.903^{\prime}$ & $126^{\circ} 09.029^{\prime}$ & Primary forest thick \\
\hline DMS & 115 & $06^{\circ} 40.571^{\prime}$ & $126^{\circ} 07.715^{\prime}$ & Few fig-trees, kalingag trees, coconut trees, residential area, laundry area \\
\hline DDS & 80 & $06^{\circ} 40.134^{\prime}$ & $126^{\circ} 06.596^{\prime}$ & Bridge, residential area, barangay hall, laundry area \\
\hline \multicolumn{5}{|c|}{ Banahaw River } \\
\hline BUS & 280 & $06^{\circ} 28.426^{\prime}$ & $126^{\circ} 11.641^{\prime}$ & Secondary forest \\
\hline BMS & 132 & $06^{\circ} 27.696^{\prime}$ & $126^{\circ} 10.122^{\prime}$ & Shrubs and coconut trees \\
\hline BDS & 17 & $06^{\circ} 26.841^{\prime}$ & $126^{\circ} 07.492^{\prime}$ & Bridge, washing/laundry area, residential area near the estuarine \\
\hline
\end{tabular}

Note: US: Upstream, MS: Midstream, DS: Downstream 


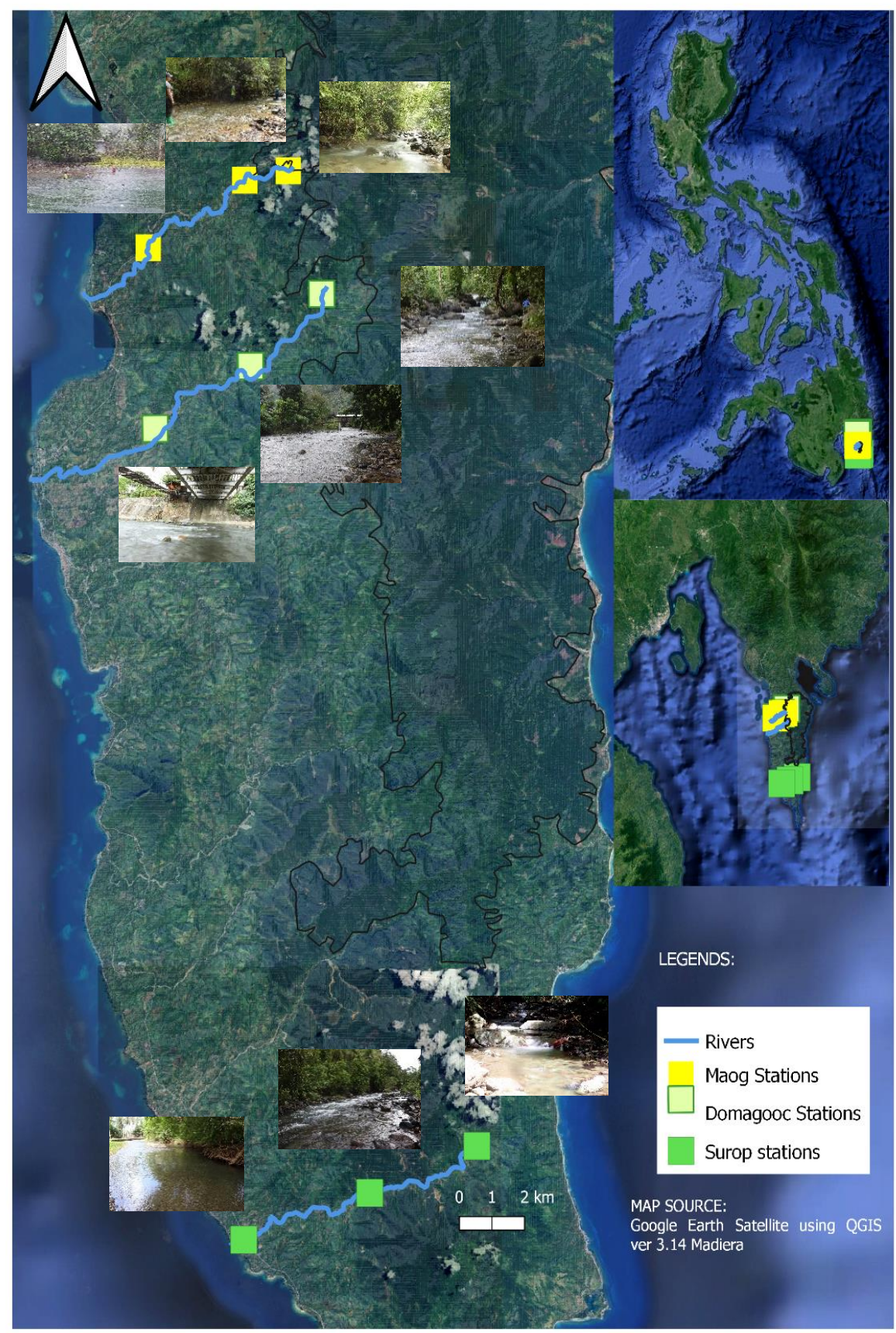

Figure 1. A. Philippine map. B. Location map of the study showing MHRWS. C. Location map of the study area showing Maog (up), Dumagooc (middle), and Banahaw (down) Rivers with the sampling stations of Mt. Hamiguitan Wildlife Sanctuary, Philippines

\section{Fish collection, identification, and preservation}

The collection of fish was done along with the three sampling stations within the river gradient using a low voltage (10V) improvised backpack electrofishing gear accompanied by a gill net with approximately $1.2 \mathrm{~mm} \mathrm{x}$ $1.2 \mathrm{~mm}$ mesh size employed in the down part of the river's gradient (Figure 2. A). A line transect of $100 \mathrm{~m}$ was established along the banks of the three rivers of each sampling station, upstream, midstream, and downstream. The electric fishing method was intentionally used to catch specific fish species of interest where seine netting is not applicable (Paller et al., 2011).

The stunned fishes caught by this method were immediately put in a bucket, documented, and initially identified in the field. Description of the live fish was done by noting their color, the number of fins and barbels if present, the shape of the tail and head, body structure, and mouth. Voucher specimens for each species were preserved in a $10 \%$ formalin solution, and other stunned fish were returned to the water after their recovery from the current shock. 


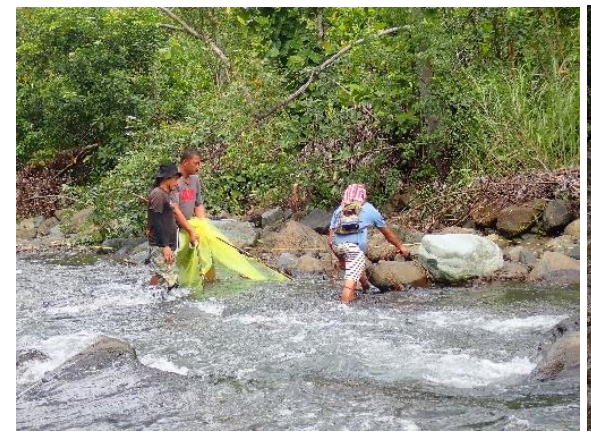

$\mathbf{A}$

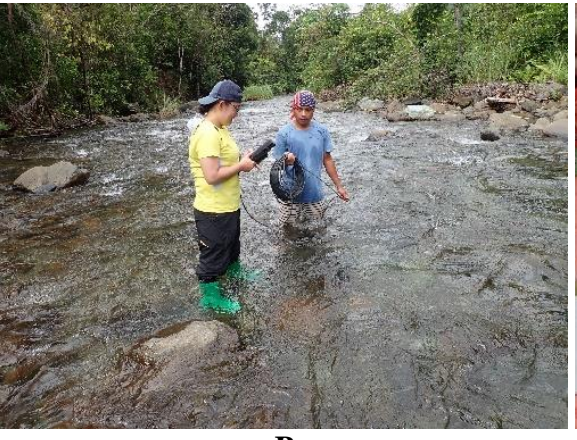

B

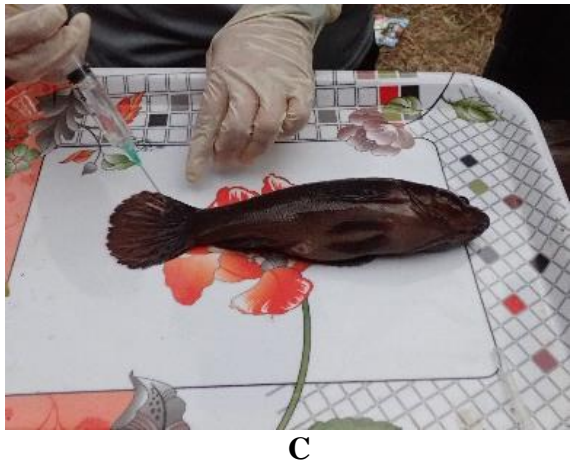

Figure 2. A. Backpack electrofishing; B. Reading using multi-parameter probe; C. Preserving voucher specimen

Collected specimens were identified and classified up to species level using the Philippine freshwater fish taxonomic keys of Herre (1953), Hubilla (2007), Paller et al. (2011), and Froese and Pauly (2018). Other published articles on fish species in Mindanao Island by Quimpang et al. (2015) and Quimpang et al. (2016) were also used for identification. Consultation with experts was also done for the verification of species. The collected voucher specimens were deposited in the CMU museum for further taxonomic analysis and identification. Fish specimens were compared with the existing literature and Pisces collection of the CMU museum for proper identification.

\section{Fish species indicators}

Whether native, endemic, or introduced, the fish status was noted based on the listing and classification of Fishbase ver.10, 2015.

\section{RESULTS AND DISCUSSION}

A total of 122 individuals of freshwater fish comprising 25 species representing 11 families were sampled from three river systems of MHRWS. Family Gobiidae was the most represented family with nine species recorded from all sites, followed by Syngnathidae (pipefishes) with four species, then by Eleotridae ( 3 spp.), and then Cyprinidae (2 spp.). Other families such as Ambassidae, Anguillidae, Butidae, Kuhliidae, Muraenidae, Poecillidae, and Rhyacichthyidae were represented by a single species. Among all species observed, Barbodes bantolanensis was the most numerous $(n=20)$ and constituted $23.7 \%$. It was found abundant upstream of Dumagooc river, few in Maug river and not observed in Banahaw river. Anguilla marmorata (Mottled eel) was the second most abundant species $(n=14)$, comprising $11.4 \%$, observed in all sites, except in the midstream of Maug and Banahaw river. The third abundant species was Stiphodon atropurpureus (Blue neon goby/balolo), with a relative abundance of $10.6 \%$ $(n=13)$. All species were identified as native in the
Philippines except Poecilia reticulata (Guppy/Butitirot), which was introduced to the country.

This study presents an updated list of species identified in the free-flowing sections of the MHRWS river systems and information on the composition of fish species along a longitudinal gradient of the river. This fish species richness assessment provides a basis for long-term monitoring of the MHRWS headwaters and their tributaries which constitutes a reference status for similar future evaluations of other river systems in Mindanao, Philippines. Although current environmental monitoring of the MHRWS river systems primarily focuses on physicochemical parameters and fish species richness, the biological quality elements and surrounding land uses are also being monitored in the area (Table 1). The continuing biodiversity assessments of fish species and physicochemical parameters will provide valuable insights on the impact of currently implemented management and conservation strategies, as well as the potential effects of climate change.

This study exhibited lower species richness than Quimpang et al. (2016). However, several misidentified species in the study, such as Schismatogobius marmoratus, which was identified as Gobioterus mindanaoensis; Lutjanus argentimaculatus identified as Waigieu seaperch; and Ryhacichthys aspro identified as Pterygoplichtys pardalis (Table $3 * *$ ). Moreover, some species identified in the previous study were not recorded in the list of freshwater fishes in the Philippines. Hence, species verification must be conducted to prove the occurrence of these species in the country. Interestingly, this study added 14 additional species to the diversity of freshwater fishes in MHRWS (Figure 3).

No reported indigenous or traditional management practices were practiced and implemented in the MHRWS river system to conserve its fish biodiversity. The locals have traditional and customized fishing gears for fishing and exploitation of the stocks. Anthropogenic activities and environmental disturbances identified in the surrounding area may affect the fish diversity and the physicochemical values in the three river systems. 
Table 2. Diversity of freshwater fish in Dumagooc, Maug, and Banahaw River, Philippines

\begin{tabular}{|c|c|c|c|c|c|c|c|c|}
\hline Family/species & DDS & DMS & DUS & MDS & MMS & BDS & BMS & BUS \\
\hline \multicolumn{9}{|l|}{ Ambassidae } \\
\hline Ambassis interrupta Bleeker, 1853 & & & & & & 1 & & \\
\hline \multicolumn{9}{|l|}{ Anguillidae } \\
\hline Anguilla marmorata Quoy \& Gaimard, 1824 & 2 & 3 & 4 & 2 & & 1 & & 2 \\
\hline \multicolumn{9}{|l|}{ Butidae } \\
\hline Oxyleotris sp. & & & & & & 1 & & \\
\hline \multicolumn{9}{|l|}{ Cyprinidae } \\
\hline Barbodes bantolanensis Day, 1914 & 5 & 2 & 20 & 1 & 1 & & & \\
\hline Puntius sp. & & & & 1 & & & & \\
\hline \multicolumn{9}{|l|}{ Eleotridae } \\
\hline Eleotris acanthopoma Bleeker, 1853 & 3 & & & 1 & 1 & & & 1 \\
\hline Eleotris fusca Forster, 1801 & 1 & 1 & 1 & 2 & 1 & 3 & & 1 \\
\hline Mogurnda mogurnda Richardson, 1844 & & & & 1 & & & & \\
\hline \multicolumn{9}{|l|}{ Gobiidae } \\
\hline Glossogobius celebius Valenciennes 1837 & & & & 1 & & & & \\
\hline Lentipes mindanaoensis Chen, 2004 & 1 & 1 & 2 & 1 & & & & \\
\hline Schismatogobius marmoratus Peters, 1868 & 1 & & & 2 & & & 1 & \\
\hline Sicyopterus lagocephalus Pallas, 1770 & & & 1 & 1 & 3 & & & \\
\hline Sicyopterus longifilis de Beaufort, 1912 & & 1 & & 1 & & & & \\
\hline Sicyopterus micrurus Bleeker, 1853 & & & & & & & 1 & \\
\hline Sicyopus zosterophorus Bleeker, 1856 & & & & & & & 1 & 1 \\
\hline Stiphodon atropurpureus Herre, 1927 & & 2 & 1 & 1 & 3 & 3 & 2 & 1 \\
\hline Stiphodon elegans Steindachner, 1879 & 1 & 1 & 3 & 1 & 1 & & 1 & \\
\hline \multicolumn{9}{|l|}{ Kuhlidae } \\
\hline Kuhlia marginata Cuvier, 1829 & & & & 1 & & 1 & & \\
\hline \multicolumn{9}{|l|}{ Muraenidae } \\
\hline Gymnothorax sp. & 1 & & & & & 1 & & \\
\hline \multicolumn{9}{|l|}{ Poeciliidae } \\
\hline Poecilia reticulate Peters, 1859 & & 3 & & & & & & \\
\hline \multicolumn{9}{|l|}{ Rhyacichthidae } \\
\hline Rhyacichthys aspro Valenciennes, 1837 & & & & & & 1 & 1 & 1 \\
\hline \multicolumn{9}{|l|}{ Syngnathidae } \\
\hline Doryichthys boaja Bleeker, 1850 & 1 & & & 1 & & & & \\
\hline Hippichthys heptagonus Bleeker, 1849 & 2 & & & 1 & & 1 & & \\
\hline Hippithichthys sp. & & & & 1 & & & & \\
\hline Microphis brachyurus Bleeker, 1854 & & & & 1 & & & & \\
\hline Grand total & 18 & 14 & 32 & 21 & 10 & 13 & 7 & 7 \\
\hline
\end{tabular}

Note: DDS: Dumagooc Downstream; DMS: Dumagooc Midstream; DUS: Dumagooc Upstream; MDS: Maug Downstream; MMS: Maug Midstream; MUS: Maug Upstream; BDS: Banahaw Downstream; BMS: Banahaw Midstream; BUP: Banahaw Upstream

The number of fishes collected in this study is lower than previous collections as 33 species were recorded by Quimpang et al. (2016) in the Maug and Dumagooc in Mt. Hamiguitan. However, the present collection is higher than the 16 species recorded by Paller et al. (2011) in Mt. Makiling Forest Reserve and five species reported by Hansel et al. (2004) in Lake Duminagat, Mt. Malindang Range Natural Park. The Maug, Dumagooc, and Banahaw rivers support one endemic species, 29 native species, and one introduced species which represents $4.16 \%$ of 48 species recorded in the country. The native species represents $14.02 \%$ of 221 native fish species here in the Philippines, while the endemic species Puntius bantolanensis represents $2.27 \%$ of 44 fish species. Mostly geographically isolated freshwater systems are home to many native and endemic fish species. Some species remain unknown and potentially face a significant threat from extinction (Herre 1953; Butler 2006). Members of the family Gobiidae, Oxudercidae, and Syngnathidae exhibited the highest species richness. Habitat loss, human interventions, pollution, and the introduction of alien species contribute to the major threats to the country's freshwater diversity (Guerrero 2002; Vidthayanon 2007).

\section{Physicochemical properties of the river}

The summary of the mean average values of physicochemical parameters of Dumagooc, Maug, and Banahaw River. This is shown in Table 2.

\section{Temperature}

An increasing level of temperature from upstream $\left(21.18{ }^{\circ} \mathrm{C}\right.$ and $23.8{ }^{\circ} \mathrm{C}$, respectively) to a downstream station $\left(25.3{ }^{\circ} \mathrm{C}, 26.6{ }^{\circ} \mathrm{C}\right.$, and $\left.27.5{ }^{\circ} \mathrm{C}\right)$, respectively, was observed in Maug and Banahaw rivers (Figure 4. A). 


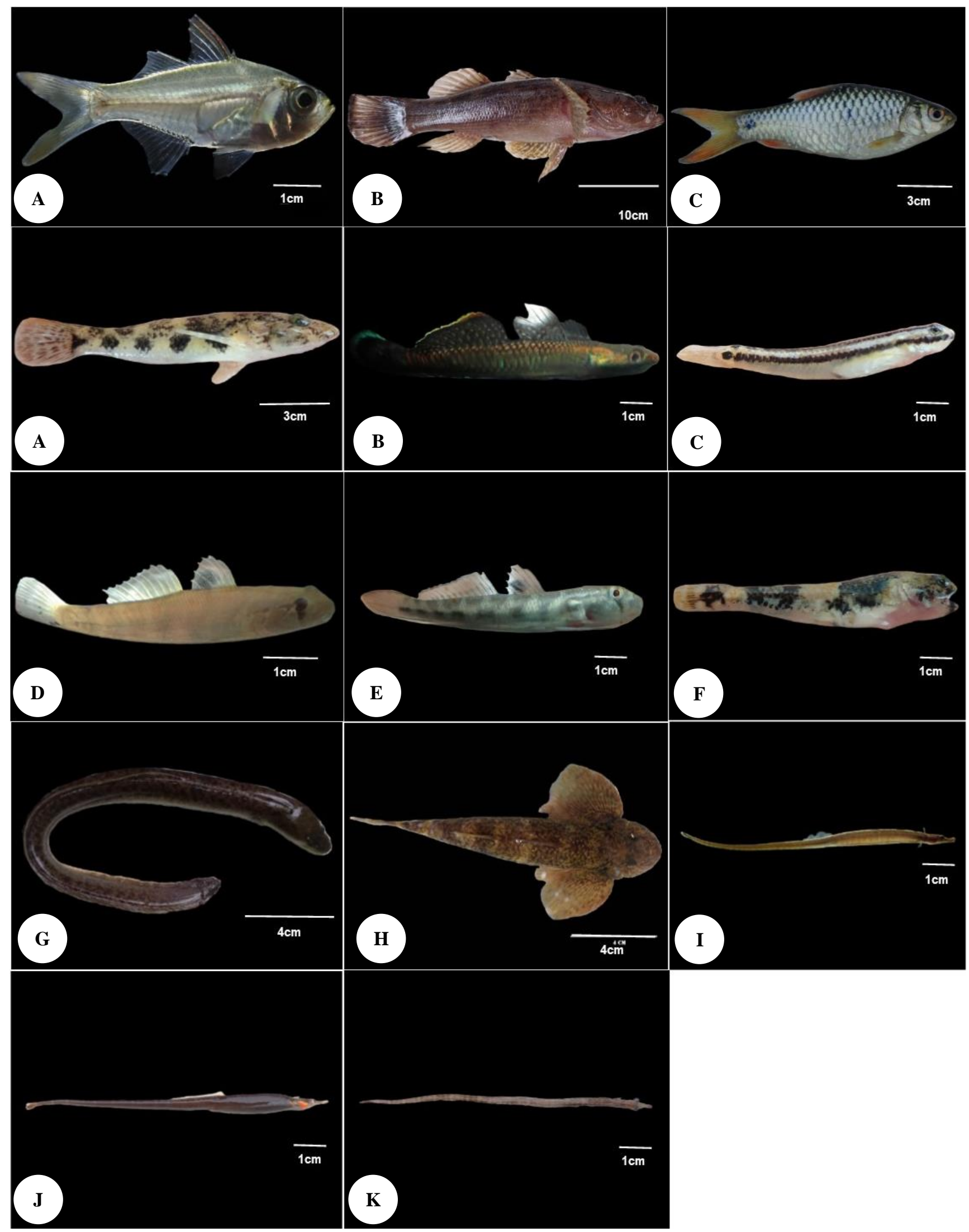

Figure 3. Additional fish species in Mt. Hamiguitan Range Wildlife Sanctuary, Philippines. A. Ambassis interrupta Bleeker, 1853 , B. Oxyeleotris sp., C. Puntius sp., D. Glossogobius celebius (Valenciennes, 1837), E. Lintipes mindanaoensis Chen, 2004, F. Sicyopterus longifinis de Beaufort, 1921, G. Sicyopus zosterophorus Bleeker, 1856, H. Schismatogobius marmoratus (Peters, 1868, I. Stiphodon elegans (Steindachner, 1879), J. Gymnothorax sp., K. Rhyacichthys aspro (Valenciennes, 1837), L. Hippichthys heptagonus (Bleeker, 1849), M. Hippichthys sp., N. Microphis brachyurus (Valenciennes, 1842) 
Table 3. Comparison of freshwater fish species in rivers of Mt. Hamiguitan Range Wildlife Sanctuary, Philippines

\begin{tabular}{|c|c|c|c|c|c|c|}
\hline \multirow{2}{*}{ Family/Species } & \multicolumn{2}{|c|}{ Quimpang et al. 2016} & \multicolumn{3}{|c|}{ In this present study } & \multirow{2}{*}{-Assessmen } \\
\hline & Maug & Dumagooc & Maug & Dumagooc & Banahaw & \\
\hline \multicolumn{7}{|l|}{ Ambassidae } \\
\hline Ambassis dussumieri (Cuvier,1828)* & & $\mathrm{x}$ & & & & Native \\
\hline Ambassis interrupta Bleeker, 1853 & & & & & $\mathrm{x}$ & \\
\hline \multicolumn{7}{|l|}{ Anguillidae } \\
\hline Anguilla marmorata Quoy \& Gaimard, 1824 & $\mathrm{x}$ & $\mathrm{x}$ & $\mathrm{x}$ & $\mathrm{x}$ & $\mathrm{x}$ & Native \\
\hline \multicolumn{7}{|l|}{ Butidae } \\
\hline Oxyeleotris lineolata (Steindachner, 1867)* & $\mathrm{x}$ & $\mathrm{x}$ & & & & Native \\
\hline Oxyleotris sp. & & & & & $\mathrm{x}$ & \\
\hline Butis amboinensis (Bleeker,1853) & & $\mathrm{x}$ & & & & Native \\
\hline Ophiocara porocephala (Valenciennes, 1837) & & $\mathrm{x}$ & & & & Native \\
\hline \multicolumn{7}{|l|}{ Cyprinidae } \\
\hline Barbodes bantolanensis (Valenciennes, 1842) & $\mathrm{x}$ & $\mathrm{x}$ & $\mathrm{x}$ & $\mathrm{x}$ & & Endemic \\
\hline Puntius sp. & & & $\mathrm{x}$ & & & \\
\hline \multicolumn{7}{|l|}{ Eleotridae } \\
\hline Allomogurnda insularis (Allen, 2003)* & $\mathrm{x}$ & $\mathrm{x}$ & & & & Native \\
\hline Eleotris oxycephala (Temminck and Schligel, 1845)* & $\mathrm{x}$ & $\mathrm{x}$ & & & & Native \\
\hline Mogurnda mogurnda (Richardson, 1845) & $\mathrm{x}$ & $\mathrm{x}$ & $\mathrm{x}$ & & & Native \\
\hline Eleotris acanthopoma (Bleeker, 1853) & & $\mathrm{x}$ & $\mathrm{x}$ & $\mathrm{x}$ & $\mathrm{x}$ & Native \\
\hline Eleotris fusca (Foster, 1801) & & $\mathrm{x}$ & $\mathrm{x}$ & $\mathrm{x}$ & $\mathrm{x}$ & Native \\
\hline \multicolumn{7}{|l|}{ Gobiidae } \\
\hline Acentrogobius janthinopterus (Bleeker,1853)* & & $\mathrm{x}$ & & & & Native \\
\hline Awaous grammepomus (Bleeker, 1849) & $\mathrm{x}$ & $\mathrm{x}$ & & & & Native \\
\hline Callogobius hastatus (McKinney and Lachner, 1978)* & & $\mathrm{x}$ & & & & Native \\
\hline Callogobius maculipinnis (Fowler, 1978) & $\mathrm{x}$ & $\mathrm{x}$ & & & & Native \\
\hline Glossogobius celebius (Valenciennes, 1837) & & & $\mathrm{x}$ & & & Native \\
\hline Gobioterus mindanensis $(\text { Herre, } 1944)^{* *}$ & $\mathrm{x}$ & $\mathrm{x}$ & & & & Native \\
\hline Lintipes mindanaoensis Chen, 2004 & & & $\mathrm{x}$ & $\mathrm{x}$ & & Native \\
\hline Oligolepis acutippenis (Valenciennes, 1837) & & $\mathrm{x}$ & & & & Native \\
\hline Sicryopterus micrurus (Bleeker, 1853) & $\mathrm{x}$ & $\mathrm{x}$ & & & $\mathrm{x}$ & Native \\
\hline Sicryopterus lagocephalus (Pallas, 1770) & $\mathrm{x}$ & $\mathrm{x}$ & $\mathrm{x}$ & $\mathrm{x}$ & $\mathrm{x}$ & Native \\
\hline Sicyopterus longifinis de Beaufort, 1921 & & & $\mathrm{x}$ & $\mathrm{x}$ & & Native \\
\hline Sicyopus zosterophorus Bleeker, 1856 & & & & & $\mathrm{x}$ & Native \\
\hline Schismatogobius marmoratus (Peters, 1868 & & & $\mathrm{x}$ & $\mathrm{x}$ & $\mathrm{x}$ & Native \\
\hline Stiphodon atropurpureus (Herre, 1927) & & $\mathrm{x}$ & $\mathrm{x}$ & $\mathrm{x}$ & $\mathrm{x}$ & Native \\
\hline Stiphodon elegans (Steindachner, 1879) & & & $\mathrm{x}$ & $\mathrm{x}$ & $\mathrm{x}$ & Native \\
\hline \multicolumn{7}{|l|}{ Hemiramphidae } \\
\hline Hyporchampos affinis (Stephanidis, 1971) & & $\mathrm{x}$ & & & & Native \\
\hline \multicolumn{7}{|l|}{ Kuhlidae } \\
\hline Kuhlia marginata (Cuvier,1829) & $\mathrm{x}$ & $\mathrm{x}$ & $\mathrm{x}$ & & $\mathrm{x}$ & Native \\
\hline Latidae & & & & & & \\
\hline Waigieu seaperch (Cuvier,1828)** & & $\mathrm{x}$ & & & & Native \\
\hline Loricarridae & & & & & & \\
\hline Pterygophicthys pardalis** & $\mathrm{x}$ & & & & & Introduced \\
\hline Mugilidae & & & & & & \\
\hline Chelon subviridis (Valenciennes,1836)* & & $\mathrm{x}$ & & & & Native \\
\hline Muraenidae & & & & & & \\
\hline Gymnothorax sp & & & & $\mathrm{x}$ & $\mathrm{x}$ & Native \\
\hline Ophicephalidae & & & & & & \\
\hline Ophicephalus striatus (Bloch, 1793)* & & $\mathrm{x}$ & & & & Introduced \\
\hline Ophichthidae & & & & & & \\
\hline Ophichthus apicalis (Bennett, 1830** & $\mathrm{x}$ & $\mathrm{x}$ & & & & Native \\
\hline Poeciliidae & & & & & & \\
\hline Gambusia affinis (Baird \&Girard, 1853) & $\mathrm{x}$ & $\mathrm{x}$ & & & & Introduced \\
\hline Poecilia reticulata (Peters, 1859 ) & $\mathrm{x}$ & $\mathrm{x}$ & & $\mathrm{x}$ & & Introduced \\
\hline Rhyacichthidae & & & & & & \\
\hline Rhyacichthys aspro (Valenciennes, 1837) & & & & & $\mathrm{x}$ & Native \\
\hline Sillaginidae & & & & & & \\
\hline Sillago sihama (Forsskål,1775) & & $\mathrm{x}$ & & & & Native \\
\hline Syngnathidae & & & & & & \\
\hline Doryichthys boaja (Bleeker, 1854) & & $\mathrm{x}$ & $\mathrm{x}$ & $\mathrm{x}$ & & Native \\
\hline Hippichthys heptagonus (Bleeker, 1849) & & & $\mathrm{x}$ & $\mathrm{x}$ & $\mathrm{x}$ & Native \\
\hline Hippichthys sp & & & $\mathrm{x}$ & $\mathrm{x}$ & & Native \\
\hline Microphis brachyurus (Valenciennes, 1842) & & & $\mathrm{x}$ & & & \\
\hline Bhanotia fasciolata (Dumirel, 1870)* & & $\mathrm{x}$ & & & & Native \\
\hline Terapontidae & & & & & & \\
\hline Terapon jarbua (Forsskål, 1775) & & $\mathrm{x}$ & & & & Native \\
\hline
\end{tabular}

Note: *Not Listed in the Philippines Freshwater Fishes (www.fishbase.com). ${ }^{* *}$ Corrected identification from Quimpang et al. (2016) 
This could be because the upstream stations were dominated by trees, shrubs, ferns, and lycophytes and were in higher elevations. Open grassland with human settlements was observed in downstream stations, and the river flow led to the open ocean. These observations contradict the study of Quimpang et al. (2020) in the two rivers of Mt. Apo, where the temperature of the two rivers' upstream stations is much higher than their downstream stations.

The optimal temperature for tropical freshwater fish species ranges from $24-27^{\circ} \mathrm{C}$, depending on the species. Most stations have suitable temperatures for fish except downstream of Banahaw river with slightly hot temperatures, possibly not suitable for some species (Table 4). Water temperatures higher than $32^{\circ} \mathrm{C}$ might cause fish to die.

\section{Total Dissolved Solids (TDS)}

A higher recorded level of Total Dissolved Solids (TDS) was observed downstream of Maug $(229.67 \mathrm{mg} / \mathrm{L})$ and Banahaw (263.67 mg/L) rivers (Figure 4G.). The recorded temperature level in the Dumagooc river midstream station was $23.7{ }^{\circ} \mathrm{C}$, much cooler than its upstream. This was due to the level of dissolved solids of around $169 \mathrm{mg} / \mathrm{L}$ in the area, where soil erosion happened during road construction. According to the study of Martinez et al. (2011), the increase in dissolved and suspended solids can increase temperature mainly because the dissolved solids absorb more heat.

\section{Turbidity}

The turbidity level in the midstream station of Maug River was around 3.26 NTU (Table 4). The high turbidity level indicates the presence of colloidal particles from discharges of sewage and industrial waste, from silt and clay during rainfall, or the presence of many microorganisms (Olatayo 2013). Hence, the landslides and soil erosion from the ongoing road widening may contribute to the turbid water of the midstream station of Maug River.

\section{Dissolved Oxygen (DO)}

The DO is one of the important regulators of the river systems' chemical processes and biological activity and the essential parameter for all aerobic organisms (Tumanda et al., 2003). Furthermore, this parameter can also be used as an index of water quality, primary production, and pollution.

Fluctuating measurements of Dissolved Oxygen (DO) were recorded in the three rivers. Moreover, in the case of Dumagooc River, a higher DO with $7.99 \mathrm{mg} / \mathrm{L}$ was observed in the midstream station with a lower temperature level (Figure 4F). This observation supports the study of George et al. (2003), stating that low DO concentrations reveal higher temperatures.

The water conductivity in the Maug River was increasing from upstream with $76.18 \mathrm{mV}$ to downstream with $150.23 \mathrm{mV}$ average measurements (Figure 4C). According to Goncharuk et al. (2010), the oxidationreduction potential or ORP, an essential indicator of natural and wastewater values ranging from $76 \mathrm{mV}$ to $344.6 \mathrm{mV}$, verifies the observed data. Furthermore, George et al. (2013) stated the inverse relationship of ORP and temperature; as the ORP value decreases, the temperature level increases.

\section{$p H$}

The $\mathrm{pH}$ means a value of the three rivers, namely Maug, Dumagooc, and Banahaw, falls within the set standard by DENR and DOH (Table 4). Almost the same $\mathrm{pH}$ range was also observed in the study of Quimpang et al. 2018 in Lake Duminagat, Mt. Malindang. Maug and Banahaw Rivers both have lower $\mathrm{pH}$ readings downstream, with an average of 7.52 and 7.54, respectively (Figure 4B). In contrast, the Dumagooc River has a lower average $\mathrm{pH}$ value of 8.08 in the midstream station. Heavy rainfall was observed during the reading of the water quality parameters. This event could be the reason for the lower $\mathrm{pH}$ reading in these rivers. This observation correlates to the study of Davie (2008) that rainfall naturally lowers the $\mathrm{pH}$ value. Moreover, Cuivillas et al. (2016) stated that the water $\mathrm{pH}$ in a river is mainly affected by its age and the chemicals discharged from communities and industries. Moreover, the $\mathrm{pH}$ of water is an important parameter that influences other components of water quality.

Table 4. Mean parameter values of Dumagooc, Maug, and Banahaw River, Philippines

\begin{tabular}{llllllllll}
\hline \multirow{2}{*}{ Parameter } & \multicolumn{3}{c}{ Dumagooc River } & \multicolumn{3}{c}{ Maug River } & \multicolumn{3}{c}{ Banahaw River } \\
\cline { 2 - 10 } & DUS & DMS & DDS & MUS & MMS & MDS & BUS & BMS & BDS \\
\hline Temperature ${ }^{\circ} \mathrm{C}$ & 24.10 & 23.70 & 25.30 & 21.18 & 23.20 & 26.60 & 23.80 & 24.80 & 27.50 \\
pH & 8.18 & 8.08 & 8.31 & 8.27 & 8.17 & 7.52 & 8.08 & 8.26 & 7.54 \\
ORP mV & 78.34 & 134.28 & 136.01 & 76.18 & 85.77 & 150.23 & 200.76 & 142.09 & 152.78 \\
SPC- $\mu$ S/cm & 0.24 & 0.26 & 0.26 & 0.21 & 0.25 & 0.35 & 0.26 & 0.34 & 0.41 \\
Turbidity (NTU) & 0.17 & 0.42 & 0.45 & 2.06 & 3.26 & 1.82 & 1.05 & 0.78 & 0.97 \\
DO mg/L & 7.84 & 7.99 & 7.91 & 7.51 & 8.16 & 7.07 & 7.72 & 7.89 & 6.61 \\
TDS mg/L & 176.11 & 169 & 172 & 138 & 163.56 & 229.67 & 168 & 227.11 & 263.67 \\
\hline
\end{tabular}

Note: DUS: Dumagooc Upstream, DMS: Dumagooc Midstream, DDS: Dumagooc Downstream, MUS: Maug Upstream, MMS: Maug Midstream, MDS: Maug Downstream, BUS: Banahaw Upstream, BMS: Banahaw Midstream, BDS: Banahaw Downstream 


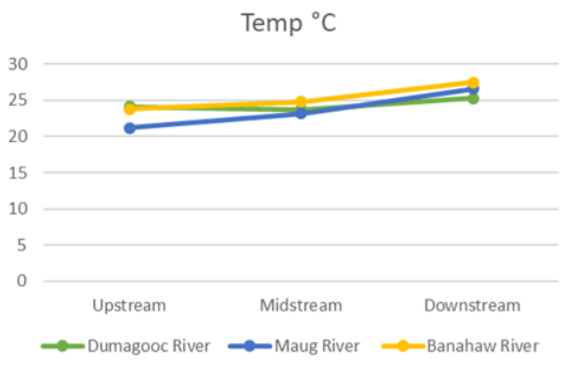

A

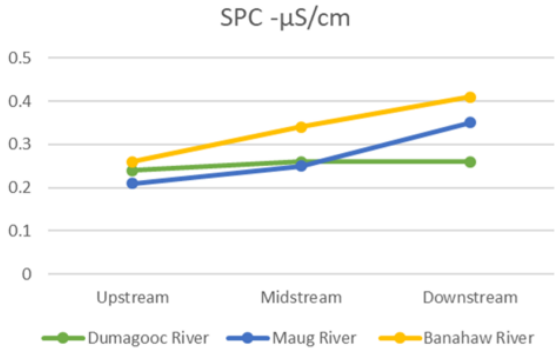

D

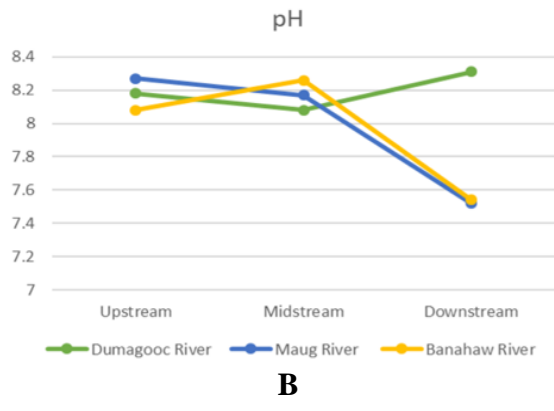

NTU

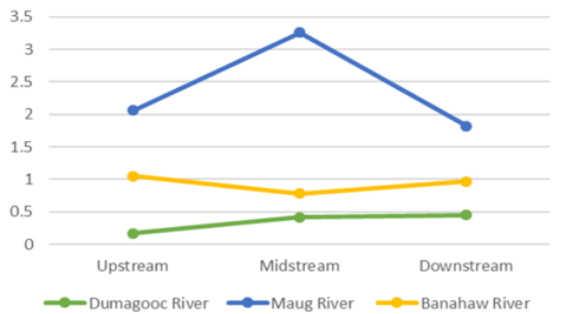

$\mathbf{E}$

TDS

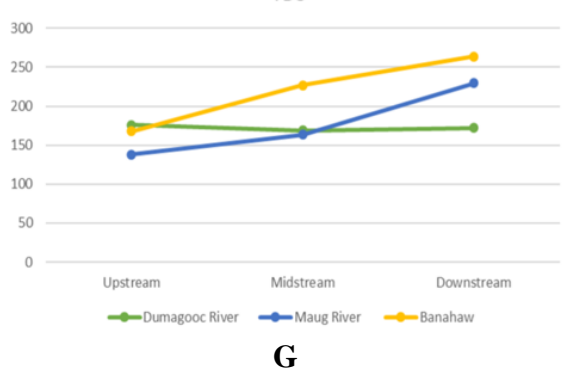

ORP $\mathrm{mV}$
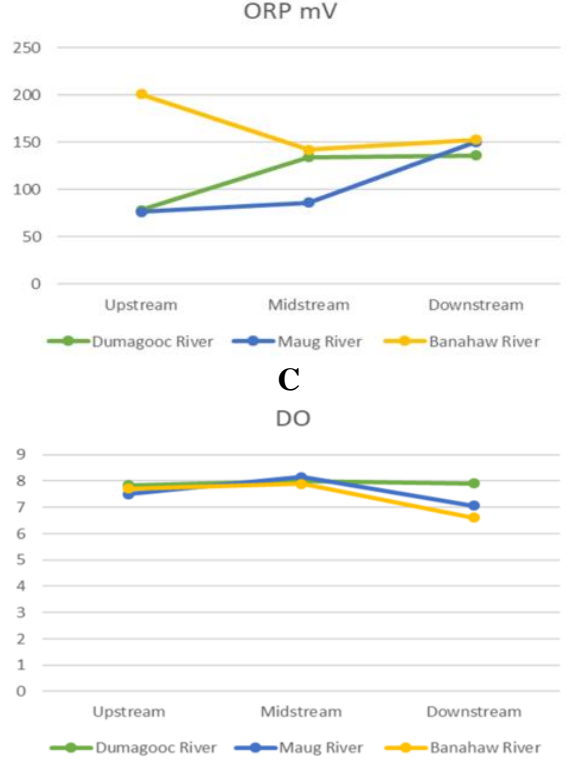

$\mathbf{F}$

Figure 4. Distribution mean values of physicochemical properties of the three river systems of Mt. Hamiguitan Range Wildlife Sanctuary. A. temperature of Maug, Dumagooc and Surop River, B. pH of Maug, Dumagooc and Surop River, C. ORP mv of Maug, Dumagooc and Surop River, D. SPC - $\mu \mathrm{S} / \mathrm{cm}$ of Maug, Dumagooc and Surop River, E. Turbidity of Maug, Dumagooc and Surop River, F. DO of Maug, Dumagooc and Surop River and G. TDS of Maug, Dumagooc and Surop River

\section{Discussion}

As to the physicochemical characteristics of the three river systems, the results showed that the DO of the sampling sites is within the minimum acceptable limit of $5 \mathrm{mg} / \mathrm{L}$ to be considered as within the standards for class $\mathrm{AA}, \mathrm{A}$, and $\mathrm{B}$ rivers. This implies that the level of organic substances in all the sampling sites has not influenced the level of DO in the water. For the NTU, the concentration of all sites reached up to the standards, which range from $0.17 \mathrm{mg} / \mathrm{L}$ to $3.26 \mathrm{mg} / \mathrm{L}$ for class AA, A, B rivers. The NTU provides the visual quality of the water with higher concentration signifying highly turbid water. The rest of the parameters, such as the $\mathrm{pH}$ and temperature, are within the standard ranges of DAO 2016-08 (DENR, 2016) and the TDS of DAO 34 (DENR, 1990). The scale morphology is recommended for future study as scale characters may constitute criteria for differentiating fish species within and among populations (Dapar et al., 2012).

Furthermore, it is evident that these riparian sites face threats brought by human activities like converting nearby lands to agricultural areas clearing the natural vegetation. The riparian ecosystems give direct benefits to the community like a source of potable water for the municipality of San Isidro, Governor Generoso Mati City Davao Oriental, hence riparian ecosystems should be included as a vital component in the management plan of the different LGUs with DENR by planting of indigenous tree species along the riparian zone.

\section{Policy recommendations}

Each river system should be mapped to indicate the areas that are still intact, disturbed, and denuded (i). The disturbed and denuded areas of the riparian ecosystems should be planted with indigenous/endemic tree species on each site and not exotic or introduced species (ii). Each riparian site is recommended to have a nursery of indigenous tree species as a source of seedlings to rehabilitate denuded or disturbed areas of the riparian ecosystem (iii). Cultivation of cash crops should be at least 20 meters away from the riverbanks (iv). Local communities should be involved in the riparian rehabilitation with the local government units in coordination with the DENR spearheading the activity (v). The management plan should be strategized with the stakeholders by planting indigenous tree species along the riparian zone for future environmental sustainability (vi). 
The present study presents an updated assessment of the fish species richness and physicochemical characteristics of selected river systems of Mt. Hamiguitan Range Wildlife Sanctuary (MHRWS). To conclude, the MHRWS supports diverse and abundant freshwater fishes that include one endemic species, 29 native species, and two introduced species. As for the physicochemical properties of the water, there is no significant difference between the three river systems. Habitat disturbance, the presence of introduced species, and other environmental factors could have influenced the species richness of the three study sites. Anthropogenic activities were also observed, which pose threats to the MHRWS river systems. Hence, the local government unit (LGU) and stakeholders must initiate effective ecological management for fish species' future protection and sustainability.

\section{ACKNOWLEDGEMENTS}

The researchers are grateful to the Biodiversity Management Bureau (BMB) and the Department of Environment and Natural Resources (DENR) of Region XI for the gratuitous permit, Central Mindanao University (CMU), Philippines, under Dr. Jesus G. Derije's administration, Center for Biodiversity Research and Extension in Mindanao (CEBREM) and Local Government Units of San Isidro, Governor Generoso and Mati for the logistics support. Most of all, sincere and utmost gratitude is conveyed to the funding agency Department of Science and Technology - Grants in Aid (DOST-GIA).

\section{REFERENCES}

Allen NJ, Meyer JP. 1991. A three-component conceptualization of organizational commitment. Human Resour Manag Rev 1 (1): 61-89. DOI: 10.1016/1053-4822(91)90011-Z.

Amoroso VB, Obsioma LD, Arlalejo JD, Aspiras RA, Capili DP, Polizon JJA, Sumile EB. 2009. Inventory and conservation of endangered, endemic, and economically important flora of Hamiguitan Range, Southern Philippines. Blumea 54 (1-3): 71-76. DOI: 10.3767/000651909X474113.

Bagarinao TU. 2001. The decline of native fishes and fisheries and the rise of aquaculture in lakes and rivers in the Philippines. In: Santiago CB, Cuvin AML, Basiao ZU (eds) Conservation and Ecological Management of Philippine Lakes in Relation to Fisheries and Aquaculture. Proceedings of the National Seminar Workshop, 21-23 October 1997.

Butler R. 2006. List of freshwater fishes for Philippines 1994-1995 generated from FishBase.org. http://www.fish.mongabay.com. [17-92021]

Cagauan AG. 2007. Exotic aquatic species introduction in the Philippines for aquaculture - A threat to biodiversity or a boom to the economy? J Environ Sci Manag 10 (1): 48-62. DOI: 10.47125/jesam/.

Cuivillas DA, Naguit V, Cuivillas AM. 2016. Physico-chemical characterization of Layawan River. IOSR J Environ Sci Toxicol Food Technol (IOSR-JESTFT) 6 (2): 69-75. DOI: 10.9790/24021006026975.

Dapar MLG, Torres MAJ, Fabricante PK, Demayo CG. 2012. Scale morphology of the Indian goatfish, Parupeneus indicus (Shaw 1803) (Perciformes: Mullidae). Adv Envi Bio 6 (4): 1426-432. DOI: $10.22587 / \mathrm{aeb}$.

Davie T. 2008. Fundamentals of Hydrology. 2nd Edition, Routledge, New York. DOI: 10.4324/9780203933664

Froese R, Pauly D. 2011 ed. FishBase. World Wide Web Electronic Publication. http://www.fishbase.org.
Froese R, Pauly D. 2018 ed. FishBase. World Wide Web Electronic Publication. http://www.fishbase.org.

George T, Franklin, LB, David HS. 2003. Wastewater Engineering Treatment and Reuse (4th ed). Metcalf and EddyInc.

Giller PS, Malmqvist B. 1998. The Biology of Streams and Rivers. Oxford University Press, Oxford.

Goncharuk VV, Bagrii VA, Mel'nik LA, Chebotareva RD, Bsahtan SY. 2010. The use of redox potential in water treatment processes. $\mathrm{J}$ Water Chem Technol 32 (1): 1-9. DOI: 10.3103/S1063455X10010017.

Guerrero RD III. 2002. Invasive Aquatic Animals in the Philippines. Special Report on their impacts and management. ASEAN Biodiversity, Oct-Dec 2002.

Heaney LR. 2001. Small mammal diversity along elevational gradients in the Philippines: an assessment of patterns and hypotheses. Global Ecol Biogeogr 10 (1): 15-39. DOI: 10.1046/j.1466-822x.2001.0027.x.

Herre AWCT. 1953. A Checklist of Philippines Fishes. Research report. Washington, D.C. Fish, and Wildlife Service, Unit of States Department Interior, Government Publishing Office.

Hubilla MFK, Primavera J. 2007. Janitor fish, Pterygoplicthys disjunctivus in Agusan Marsh: A threat to freshwater biodiversity. J Environ Sci Manag 10 (1): 10-23. DOI: 10.47125/jesam.

Kang B, He D, Perrett L, Wang H, Hu W, Deng W, Wu Y. 2009. Fish and fisheries in the Upper Mekong: Current assessment of the fish community, threats, and conservation. Rev Fish Biol Fish 19 (4): 465 480. DOI: 10.1007/s11160-009-9114-5.

Karger DN, Kluge J, Abrahamcyzk S, Salazar L, Hohmeier J, Lehnert M, Amoroso VB, Kessler M. 2012. Bryophyte cover on trees as proxy for air humidity in the tropics. Ecol Indic 20: 277-281. DOI: 10.1016/j.ecolind.2012.02.026.

Kottelat M, Whitten AJ, Kartikasari SN, Wirjoatmodjo S. 1993. Freshwater Fishes of Western Indonesia and Sulawesi. Periplus Editions, Hongkong.

Laffaille P, Acou A, Guillouet J, Legult A. 2005. Temporal change in European eel, Anguilla anguilla, stock in a small catchment after installation of fish passes. Fish Manag Ecol 12 (2): 123-129. DOI: 10.1111/j.1365-2400.2004.00433.x.

Mallari NAD, Tabaranza BR, Jr., Crosby MJ. 2001. Key Conservation Sites in the Philippines: A Haribon Foundation and BirdLife International Directory of Important Bird Areas. Bookmark, Inc., Makati City, Philippines.

Manacop PR. 1953. The life history and habits of the goby, Sicyopterus extraneus Herre (Anga) Gobiidae, with an account of the goby-fry fishery of Cagayan River, Oriental Misamis Province, Mindanao, Philippines. Philippine J Fish 2: 1-60.

Martinez FB, Galera IC. 2011. Monitoring and evaluation of the water quality of Taal Lake, Talisay, Batangas, Philippines. Acad Res Intl 1 (1): 229.

Myers GS. 1960. The endemic fish fauna of Lake Lanao, and the evolution of higher taxonomic categories. Evolution 14 (3): 323-333. DOI: $10.2307 / 2405975$.

Ng PKL, Tan HH, Lim KKP, Kottelat M. 1998. Peat swamp fishes of Southeast Asia: Diversity under threat. Raffles Museum of Biodiversity Research, Department of Biological Sciences, The National University of http://rmbr.nus.edu.sg/articles/dbs/peat.html. [18-9-2021]

Olatayo AA. 2013. Assessment of physicochemical parameters of waters in Ilaje Local Government Area of Ondo State, Nigeria. Intl J Fish Aquat Stud 1 (5): 84-92.

Ong PS, Afuang LE, Rosell-Amball RG (eds) 2002. Philippine Biodiversity Conservation Priorities, a 2nd iteration of the national biodiversity strategy and action plan: final report. Department of Environment and Natural Resources, Conservation International Philippines, Biodiversity Conservation Program, U.P. Center for Integrative and Development Studies, Quezon City.

Paller VGU, Labatos BV, Lontoc BM, Matalog OE, Ocampo PP. 2011. Freshwater fish fauna in watersheds of Mt. Makiling Forest reserve, Laguna, Philippines. Philipp J Sci 140 (2): 195-206.

Quimpang VT, Cudal MC, Opiso EM, Tubongbanua RMJr. 2020. Fish abundance and physico-chemical properties of Matingao River and Marbel River, Mt. Apo Natural Park, Mindanao, Philippines. CMU J Sci 23 (2): 14-20. DOI: 10.52751/DRFA8273.

Quimpang VT, Cudal MG, Leaño EP, Opiso EM, Calunsag VLB, Amoroso VB. 2018. Physicochemical characteristics and fish fauna composition of Lake Duminagat, Mt. Malindang Range Natural Park, Philippines. DOI: 10.7828/jmds.v7i2.1222. 
Quimpang VT, Opiso EM, Cudal MC, Coquilla KL, Buot GA, Forten RRC, Bruno AGT, Amoroso VB. 2015. Assessment and monitoring of fish species in mountain streams and lakes of Mindanao LTER sites. Asian J Biodivers 6 (1): 100-121. DOI: 10.7828/ajob.v6i1.697.

Quimpang VT, Opiso EM, Salolog MCS, Tubongbanua RM Jr., Amoroso VB. 2016. Fish species composition, distribution, and diversity in two selected rivers of Mt. Hamiguitan Range Wildlife Sanctuary (HRWS), San Isidro, Davao Oriental, Mindanao, Philippines. Asian J Biodivers 7 (1): 96-111. DOI: 10.7828/ajob.v7i1.869.

Sarkar UK, Pathak AK, Lakra WS. 2008. Conservation of freshwater fish resources of India: New approaches, assessment, and challenges. Biodivers Conserv 17 (10): 2495-2511. DOI: 10.1007/s10531-0089396-2.

Tumanda M, Roa EC, Gorospe JG, Daitia M, Dejarme S, Gaid R. 2003 Limnological and Water Quality Assessment of Lake Mainit. Mindanao State University at Naawan.

Uy WH, De Guzman AB, Acuña RE, Roa RL. 2015. Aquatic biodiversity of Lake Mainit, Southern Philippines. DOI 10.48031/msunjear.2015.03.01
Vallejo AN JR. 1986. Fishes of Laguna de Bay. Nat App Sci Bull 37 (4): 285-346. DOI: 10.1088/0031-9112/37/7/015.

Vannote RL, Minshall GW, Cummins KW, Sedell JR, Cushring CE. 1980. The river continuum concept. DOI: 10.1139/f80-017

Vedra SA, Ocampo PP, de Lara AV, Rebancos CM. 2013. Indigenous Goby population in Mandulog river system and its conservation by communities in Iligan City, Philippines. J Environ Sci Manag 16 (2): 11-18. DOI: $10.47125 /$ jesam/.

Vedra SA, Ocampo PP. 2014. The fishery potential of freshwater gobies in Mandulog River, Northern Mindanao, Philippines. Asian J Agri Dev 11: 1. DOI: 10.22004/ag.econ.200295.

Vidthayanon C. 2007. Overview on freshwater fishes of the Philippines. Unpublished Paper presented during the National Training Course on Freshwater Fish Identification, 18 October 2007. UPLB Limnological Research Station, Zonal Center 2, PCAMRD, IBS-UPLB, PIBCFI, Chester Zoo, and WorldFish Philippine Center, SEARCA, Los Baños. 